\title{
Pemahaman Guru Pendidikan Anak Usia Dini terhadap Perencanaan Pembelajaran Tematik
}

\author{
Helly Apriyanti ${ }^{凶}$ \\ Program studi PG-PAUD IKIP PGRI Jember
}

\begin{abstract}
Abstrak
Penelitian ini bertujuan untuk mendeskripsikan pemahaman guru pendidikan anak usia dini terhadap perencanaan pembelajaran tematik. Fokus penelitian ini yaitu sejauh mana guru pendidikan anak usia dini memahami tentang perencanaan pembelajaran tematik. Penelitian ini merupakan penelitian deskriptif yang dilaksanakan di Raudhatul Athfal (RA) SeKecamatan Ajung. Populasi di dalam penelitian ini yaitu guru-guru RA Se-Kecamatan Ajung dimana pemilihan sampel dilakukan dengan simple random sampling. Alat pengumpulan data dalam penelitian ini dengan menggunakan angket. Dari hasil analisis data diperoleh kesimpulan bahwa rata-rata pemahaman guru pendidikan anak usia dini terhadap perencanaan pembelajaran tematik yakni sebesar $76 \%$, sehingga dapat dikategorikan bahwa guru sudah paham mengenai aspek perencanaan pembelajaran tematik.
\end{abstract}

Kata Kunci : Pemahaman, Guru PAUD, Perencanaan, Pembelajaran Tematik

\begin{abstract}
The purpose of this research is to describe the understanding of early childhood education teachers on thematic learning planning. The focus of this research is the extent to which early childhood education teachers understand about thematic learning planning. This research is a descriptive research conducted at Raudhatul Athfal (RA) Se-Kecamatan Ajung. The population in this research are teachers of RA Se-Kecamatan Ajung where the sample selection is done by simple random sampling. Data collection tool in this research by using questionnaire. From the result of data analysis, it can be concluded that the average of early childhood teacher's understanding on thematic learning planning is $76 \%$, so that it can be categorized that the teacher has understood the aspect of thematic learning planning.
\end{abstract}

Keywords: Understanding, Early Childhood Education Teacher, Planning, Thematic Learning

@ Jurnal Obsesi Prodi PG-PAUD FIP UPTT 2017

$\triangle$ Corresponding author :

Address : Sumbersari, Jember, Indonesia

ISSN 2356-1327 (Media Cetak)

Email : helly982@yahoo.co.id

ISSN 2549-8959 (Media Online) 


\section{PENDAHULUAN}

Pendidikan anak usia dini (PAUD) dilakukan sejak anak lahir sampai dengan usia 6 tahun dengan disesuaikan dengan tingkat perkembangan anak. Usia lahir sampai usia 6 tahun disebut juga dengan masa keemasan (golden age) dimana anak dapat dengan cepat menerima rangsangan.

Sebagaimana tercantum dalam

Peraturan Menteri Pendidikan dan Kebudayaan (Permendikbud) Nomor 146 Tahun 2014 tentang Kurikulum 2013 Pendidikan Anak Usia dini pasal 1 bahwa pendidikan anak usia dini yang selanjutnya disingkat PAUD merupakan suatu upaya pembinaan yang ditujukan kepada anak sejak lahir sampai dengan usia 6 (enam) tahun yang dilakukan melalui pemberian rangsangan pendidikan untuk membantu pertumbuhan, perkembangan jasmani dan rohani supaya anak siap dalam memasuki pendidikan lebih lanjut.

Peran guru terhadap pendidikan anak usia dini sangatlah penting dalam mengembangkan keenam aspek perkembangan anak usia dini yang meliputi aspek nilai agama dan moral, aspek fisik-motorik, aspek kognitif, aspek bahasa, aspek sosial-emosional dan aspek seni. Peran guru sebagai pendidikpun tidak terlepas dari bagaimana seorang guru dapat melaksanakan proses pembelajaran dengan membuat rasa senang bagi siswanya.

Istilah pendidik pada hakikatnya terkait sangat erat dengan istilah guru secara umum. Guru diidentifikasikan sebagai : (1) orang yang memiliki kharisma atau wibawa hingga perlu untuk ditiru dan diteladani; (2) orang dewasa yang secara sadar bertanggung jawab dalam mendidik, mengajar dan membimbing anak; (3) orang yang memiliki kemampuan merancang program pembelajaran serta mampu menata dan mengelola kelas dan (4) suatu jabatan atau profesi yang memerlukan keahlian khusus (Sujiono, 2013 : 10).

Profesionalisme seorang guru sangat dituntut dalam keberhasilan proses pembelajaran di kelas. Empat (4) kompetensi yang harus dimiliki oleh seorang guru yaitu kompetensi pedagogik, kompetensi profesional, kompetensi kepribadian dan kompetensi sosial.

Proses pembelajaran pada anak usia dini hendaknya dilakukan dengan tujuan memberikan konsep-konsep dasar yang memiliki kebermaknaan bagi anak melalui pengalaman nyata yang memungkinkan anak untuk menunjukan aktivitas dan rasa ingin tahu (curiousity) secara optimal (Sujiono, $2013: 2$ ).

Pembelajaran yang dilaksanakan pada pendidikan anak usia dini yaitu pembelajaran tematik. Sebagaimana tercantum dalam lampiran I Peraturan Menteri Pendidikan dan Kebudayaan (Permendikbud) Nomor 146 Tahun 2014 tentang kurikulum 2013 Pendidikan Anak Usia dini bahwa karakteristik kurikulum 2013 pendidikan anak usia dini menggunakan pembelajaran tematik dengan pendekatan saintifik dalam pemberian rangsangan pendidikan.

Proses pembelajaran akan berhasil jika seorang guru mampu memahami perencanaan pembelajaran dengan baik. Untuk itu sebelum proses pembelajaran dilaksanakan seyogyanya guru harus merancang pembelajaran. Perencanaan pembelajaran merupakan hal yang sangat penting dalam mengembangkan kurikulum PAUD. Sebagai seorang pendidik profesional membuat perencanaan pembelajaran merupakan tanggung jawab dalam mengembangkan seluruh potensi anak. Perencanaan dimaksudkan untuk mengarahkan pembelajaran agar dapat berjalan sebagaimana mestinya guna mencapai tujuan yang diinginkan.

Berdasarkan uraian di atas maka tujuan dari penelitian ini yaitu mendeskripsikan pemahaman guru pendidikan anak usia dini terhadap perencanaan pembelajaran tematik.

\section{Pemahaman}

Diuraikan dalam Kamus Besar Bahasa Indonesia bahwa pemahaman adalah sesuatu hal yang kita pahami dan kita mengerti dengan benar, sehingga dapat diartikan bahwa pemahaman adalah suatu proses, cara memahami, cara mempelajari sesuatu dengan baik supaya paham dan mempunyai pengetahuan. 
Menurut Bloom pemahaman adalah kemampuan seseorang untuk mengerti atau memahami sesuatu setelah sesuatu itu diketahui dan diingat. Sedangkan menurut Purwanto (2010: 44) bahwa pemahaman atau komprehensi adalah tingkat kemampuan yang mengharapkan testee mampu memahami arti atau konsep, situasi, serta fakta yang diketahuinya.

Berdasarkan teori yang sudah dikemukakan di atas dapat disimpulkan bahwa pemahaman adalah kesanggupan, kemampuan untuk dapat mendefinisikan, menterjemahkan sesuatu dan mengusai hal tersebut dengan memahami makna tersebut. Dengan demikian pemahaman merupakan kemampuan dalam memaknai hal-hal yang terkandung dalam suatu teori maupun konsep-konsep yang dipelajari.

\section{Guru PAUD}

Menurut Nuh (Halimah, 2016: 283) pendidik atau sering disebut dengan guru berasal dari bahasa sansekerta yaitu " $G u$ artinya kegelapan, $R u$ artinya penghancur". Jadi guru harus menjadi energi untuk melenyapkan kegelapan, sekaligus menjadi sumber cahaya kehidupan bagi anak didik pada khususnya, dan masyarakat pada umumnya.

UU Nomor 20 Tahun 2003 pasal 1 ayat 6 berbunyi pendidik adalah tenaga yang berkualifikasi sebagai guru, dosen, konselor, pamong belajar, widyaiswara, tutor, instruktur, fasilitator dan sebutan lain yang sesuai dengan kekhususannya, serta berpartisipasi dalam menyelenggarakan pendidikan.

Menurut Eberts dan Gisler (Halimah, 2016 : 283) hal yang sangat penting dalam memilih karier untuk menjadi pendidik anak usia dini harus memiliki pengetahuan tentang perkembangan anak didik, mampu membuat program yang akan membantu setiap anak didik menjadi individu seutuhnya.

Peran guru anak usia dini lebih sebagai mentor atau fasilitator, dan bukan presenter ilmu pengetahuan semesta, karena ilmu tidak dapat ditransfer dari guru kepada anak tanpa keaktifan anak itu sendiri. Dalam proses pembelajaran, tekanan harus diletakan pada pemikiran guru. Oleh karenanya, penting bagi guru untuk dapat mengerti cara berfikir anak, mengembangkan dan menghargai pengalaman anak, memahami bagaimana anak mengatasi suatu persoalan, menyediakan dan memberikan materi sesuai dengan taraf perkembangan kognitif anak agar lebih berhasil membantu anak berfikir dan membentuk pengetahuan, menggunakan berbagai metode belajar yang bervariasi yang memungkinkan anak aktif mengkonstruksi pengetahuan (Sujiono, 2012 : 13).

Empat (4) kompetensi yang harus dimiliki guru PAUD sesuai dengan Peraturan Menteri Pendidikan dan Kebudayaan Nomor 137 Tahun 2014 tentang Standar Nasional Pendidikan Anak Usia Dini sebagai berikut :

1. Kompetensi Pedagogik

a. Mengorganisasikan aspek perkembangan sesuai dengan karakteristik anak usia dini.

b. Menganalisis teori bermain sesuai aspek dan tahapan perkembangan, kebutuhan, potensi, bakat, dan minat anak usia dini.

c. Merancang kegiatan pengembangan anak usia dini berdasarkan kurikulum.

d. Menyelenggarakan kegiatan pengembangan yang mendidik.

e. Memanfaatkan teknologi, informasi dan komunikasi untuk kepentingan penyelenggaraan kegiatan pengembangan yang mendidik.

f. Mengembangan potensi anak usia dini untuk pengatualisasian diri

g. Berkomunikasi secara efektif, empatik dan santun.

h. Menyelenggarakan dan membuat laporan penilaian, evaluasi proses dan hasil belajar anak usia dini.

i. Menentukan lingkup sasaran asesmen proses dan hasil pembelajaran pada anak usia dini.

j. Menggunakan hasil penilaian, pengembangan dan evaluasi program untuk kepentingan pengembangan anak usia dini. 
k. Melakukan tindakan reflektif, korektif dan inovatif dalam meningkatkan kualitas proses dan hasil pengembangan anak usia dini.

2. Kompetensi Profesional

a. Mengembangkan materi, struktur dan konsep bidang keilmuan yang mendukung serta sejalan dengan kebutuhan dan tahapan perkembangan anak usia dini.

b. Merancang berbagai kegiatan pengembangan secara kreatif sesuai dengan tahapan perkembangan anak usia dini.

c. Mengembangkan keprofesionalan secara berkelanjutan dengan melakukan tindakan refletif.

3. Kompetensi kepribadian

a. Bertindak sesuai dengan norma, agama, hukum, sosial dan kebudayaan nasional Indonesia.

b. Menampilkan diri sebagai pribadi yang jujur, berakhlak mulia, dan teladan bagi anak usia dini dan masyarakat.

c. Menampilkan diri sebagai pribadi yang mantap, stabil, dewasa, arif, bijaksana, dan berwibawa

d. Menunjukan etos kerja, tanggungjawab yang tinggi, rasa percaya diri, dan bangga menjadi guru.

e. Menjungjung tinggi kode etik guru

4. Kompetensi sosial

a. Bersikap inklusi, bertindak objektif serta tidak diskriminatif karena pertimbangan jenis kelamin, agama, ras, suku, kondisi fisik, latar belakang keluarga, dan status sosial ekonomi.

b. Berkomunikasi secara efektif, empatik, dan santun dengan sesama pendidik, tenaga kependidikan, orang tua dan masyarakat.

c. Beradaptasi dalam keanekaragaman sosial budaya bangsa Indonesia.

d. Membangun komunikasi profesi

Berdasarkan isi dari

Permendikbud tersebut bahwasannya kompetensi pedagogik merupakan kompetensi yang mengharuskan guru mampu merancang, melaksanakan, mengevaluasi kegiatan pembelajaran, kompetensi profesional merupakan kompetensi yang berkaitan dengan merancang dan mengaplikasikan ilmu yang dimiliki, kompetensi kepribadian bahwasannya seorang guru harus menjadi suri teladan bagi anak didiknya, sedangkan kompetensi sosial bagaimana guru mampu menempatkan diri baik di lingkungan sekolah maupun masyarakat.

\section{Perencanaan}

Cunningham (Uno, 2006 : 1) mengemukakan perencanaan ialah menyeleksi dan menghubungkan pengetahuan, fakta, imajinasi dan asumsi untuk masa yang akan datang dengan tujuan memvisualisasikan dan memformulasi hasil yang diinginkan, urutan kegiatan yang diperlukan dan perilaku dalam batas-batas yang dapat diterima yang akan digunakan dalam penyelesaian.

Perencanaan adalah hubungan antara apa yang ada sekarang (what is) dengan bagaimana seharusnya (what should be) yang bertalian dengan kebutuhan, penentuan tujuan, prioritas, program dan alokasi sumber (Steller dalam Uno, 2006: 1 ). Perencanaan adalah suatu cara untuk mengantisipasi dan menyeimbangkan perubahan (Robbins dalam Uno, 2006 : 1). Perencanaan yakni suatu cara yang memuaskan untuk membuat kegiatan dapat berjalan dengan baik, disertai dengan berbagai langkah yang antisipatif guna memperkecil keenjangan yang terjadi sehingga kegiatan tersebut mencapai tujuan yang telah ditetapkan (Uno, 2006 : 2).

Kauffman (Asmawati, 2014 : 1) menyatakan bahwa perencanaan adalah suatu proyeksi tentang apa yang diperlukan dalam rangka mencapai tujuan yang bernilai. Newman mengemukakan perencanaan adalah menentukan apa yang akan dilakukan (Majid, $2011: 15$ ).

Terry mengemukakan perencanaan adalah menetapkan pekerjaan yang harus dilakukan oleh kelompok untuk mencapai tujuan yang digariskan. Banghart dan Trull mengemukakan bahwa perencanaan adalah 
awal dari semua proses yang rasional dan mengandung sifat optimisme yang didasarkan atas kepercayaan bahwa akan dapat mengatasi berbagai macam permasalahan. Sedangkan Sudjana mengatakan bahwa perencanaan adalah proses yang sistematis dalam pengambilan keputusan tentang tindakan yang akan dilakukan pada waktu yang akan datang (Majid, $2011:$ 16).

\section{Pembelajaran Tematik}

Pembelajaran tematik merupakan suatu strategi pembelajaran yang melibatkan beberapa bidang pengembangan untuk memberikan pengalaman yang bermakna kepada anak (Kostelknik dalam Sujiono, 2013: 211). Sedangkan menurut Sujiono (2013: 211) Pembelajaran tematik diajarkan pada anak karena pada umumnya mereka masih melihat segala sesuatu sebagai satu keutuhan (holistic) perkembangan fisiknya tidak pernah dapat dipisahkan dengan perkembangan mental, sosial dan emosional.

Pembelajaran tematik adalah pembelajaran terpadu yang menggunakan tema untuk mengaitkan beberapa mata pelajaran sehingga memberikan pengalaman yang bermakna bagi peserta didik (Martiono dalam Saptiani, 2016 : 24). Pembelajaran tematik lebih menekankan pada penerapan konsep belajar sambil melakukan sesuatu (learning by doing). Oleh karena itu, guru perlu mengemas atau merancang pengalaman belajar yang akan mempengaruhi kebermaknaan belajar siswa (Joni, 2009 : 43).

Dalam model pembelajaran tematik terpadu di PAUD, kegiatan-kegiatan yang dilakukan untuk satu tema, sub tema, subsub tema dirancang untuk mencapai secara bersama-sama kompetensi sikap, pengetahuan dan keterampilan dengan mencakup sebagian atau seluruh aspek pengembangan (Permendikbud, 2014 : 3).

Lebih lanjut diuraikan dalam Permendikbud Nomor 146 Tahun 2014 lampiran 4, pembelajaran tematik terpadu dilaksanakan dalam tahapan kegiatan pembukaan, kegiatan inti dan kegiatan penutup. Kegiatan pembukaan dilakukan untuk menyiapkan anak secara psikis dan fisik untuk mengikuti proses pembelajaran. Kegiatan Inti merupakan upaya kegiatan bermain yang memberikan pengalaman belajar secara langsung kepada anak sebagai dasar pembentukan sikap, perolehan pengetahuan dan keterampilan. Kegiatan penutup merupakan kegiatan yang bersifat penenangan.

Kekuatan pembelajaran tematik (Sujiono dalam Sujiono, 2013: 212) yaitu (1) pengalaman dan kegiatan belajar relevan dengan tingkat perkembangan dan kebutuhan anak, (2) menyenangkan karena bertolak dari minat dan kebutuhan anak, (3) hasil belajar akan bertahan lebih lama karena lebih berkesan dan bermakna, (4) mengembangkan keterampilan berfikir anak dengan permasalahan yang dihadapi, dan (5) menumbuhkembangkan keterampilan sosial dalam bekerja sama, toleransi, komunikasi, dan tanggap terhadap gagasan orang lain.

\section{METODE}

Metode penelitian adalah suatu cara kerja agar dapat mengumpulkan data dan data tersebut diolah untuk menghasilkan data yang dapat memecahkan permasalahan penelitian. Metode Penelitian ini menggunakan metode penelitian deskriptif. Penelitian Deskriptif adalah penelitian yang berusaha mendeskripsikan suatu gejala, peristiwa, kejadian yang terjadi saat sekarang (Noor, $2011: 34$ ).

Penelitian ini bertujuan untuk mengetahui bagaimana tingkat pemahaman guru PAUD terhadap perencanaan pembelajaran tematik, setelah data diperoleh dan dianalisis sehingga didapat suatu gambaran tentang tingkat pemahaman guru PAUD terhadap perencanaan pembelajaran tematik.

Subjek yang menjadi sumber informasi dalam penelitian ini adalah guru pendidikan anak usia dini di RA Se-Kecamatan Ajung. Peneliti tidak meneliti seluruh guru yang ada di RA Se-Kecamatan Ajung tetapi peneliti mengambil sample menggunakan simple random sampling. Simple random sampling diartikan sebagai pengambilan anggota sampel dari populasi dilakukan secara acak tanpa memperhatikan strata yang ada dalam populasi 
yang ada. Adapun populasi guru RA di Kecamatan Ajung sebanyak 55 guru, dan sampel yang diambil sebanyak 28 guru.

Instrumen dalam penelitian ini mempergunakan kuesioner (angket). Seperti yang diungkapkan oleh Sugiyono (2016:142) kuesioner merupakan teknik pengumpulan data yang dilakukan dengan cara memberikan seperangkat pertanyaan atau pernyataan tertulis kepada responden untuk dijawabnya.

Angket yang dimaksud dalam penelitian ini dibuat berupa 20 daftar pernyataan yang disampaikan kepada responden untuk mendapatkan data dari responden mengenai pemahaman guru PAUD terhadap perencanaan pembelajaran tematik di RA Se-Kecamatan Ajung Kabupaten Jember. Model angket yang digunakan adalah skala likert dengan menggunakan gradasi :

\begin{tabular}{|l|c|}
\hline \multicolumn{1}{|c|}{ Gradasi } & Skor \\
\hline Sangat Paham (SP) & 5 \\
\hline Paham (P) & 4 \\
\hline Kurang Paham (KP) & 3 \\
\hline Tidak Paham (TP) & 2 \\
\hline $\begin{array}{l}\text { Sangat tidak paham } \\
\text { (STP) }\end{array}$ & 1 \\
\hline
\end{tabular}

penelitian ini dilakukān dengă tahapan yang pertama menyeleksi data yaitu pemeriksaan terhadap kemungkinan adanya kesalahan dalam daftar pernyataan. Tabulasi data yaitu proses pengelompokan data dengan menjumlahkannya kemudian memasukan data kedalam tabel-tabel sehingga diketahui frekuensinya. Penyajian data bertujuan untuk melihat perbandingan besar kecilnya frekuensi jawaban angket yang diberikan responden karena jumlah jawaban responden pada setiap itemnya berbeda. Data yang telah diolah dianalisis kemudian disajikan dalam bentuk tabel. Untuk menghitung persentase dengan menggunakan rumus statistik sederhana mengacu pada pendapat Anas Sudijono (2003 : 43) yaitu :

$$
p=\frac{f}{n} x 100 \%
$$

Keterangan :

$\mathrm{p}=$ angka presentase

$\mathrm{f}=$ frekuensi yang sedang dicari persentasenya $\mathrm{n}=$ jumlah frekuensi/banyaknya individu

$100 \%$ = bilangan tetap

Kesimpulan dibuat berdasarkan persentase rata-rata tingkat pemahaman guru yang telah dihitung, sehingga dapat diketahui berapa persen rata-rata tingkat pemahaman guru terhadap perencanaan pembelajaran tematik.

\section{HASIL DAN PEMBAHASAN}

Ajung merupakan salah satu kecamatan yang berada di Kabupaten Jember, terdapat 16 Radautul Athfal (RA) yang berdiri di Kecamatan Ajung Kabupaten Jember. Tujuan dari penelitian yang dilaksanakan di RA SeKecamatan Ajung yaitu untuk mengetahui bagaimana tingkat pemahaman guru pendidikan anak usia dini terhadap perencanaan pembelajaran tematik.

Hasil penelitian dari aspek perencanaan pembelajaran tematik dapat diuraikan di bawah ini:

\begin{tabular}{|c|c|c|c|c|c|c|c|c|}
\hline $\begin{array}{c}\text { item } \\
\text { pernya- } \\
\text { taan }\end{array}$ & $\mathrm{fP}(5)$ & $\mathrm{P}(4)$ & $\mathrm{KP}(3)$ & $\mathrm{TP}(2)$ & $\mathrm{STP}(1)$ & \multirow{2}{*}{ Skor } & $\begin{array}{c}\text { Persen-tase } \\
(\%)\end{array}$ & Kategori \\
\cline { 2 - 6 } item 1 & 0 & 14 & 14 & 0 & 0 & 98 & 70 & Paham \\
\hline item 2 & 0 & 9 & 19 & 0 & 0 & 93 & 66 & Paham \\
\hline item 3 & 0 & 21 & 7 & 0 & 0 & 105 & 75 & Paham \\
\hline item 4 & 0 & 2 & 26 & 0 & 0 & 86 & 61 & Paham \\
\hline item 5 & 0 & 28 & 0 & 0 & 0 & 112 & 80 & Sangat Paham \\
\hline item 6 & 0 & 28 & 0 & 0 & 0 & 112 & 80 & Sangat Paham \\
\hline item 7 & 0 & 27 & 1 & 0 & 0 & 111 & 79 & Paham \\
\hline item 8 & 0 & 24 & 4 & 0 & 0 & 108 & 77 & Paham \\
\hline item 9 & 0 & 28 & 0 & 0 & 0 & 112 & 80 & Sangat Paham \\
\hline 1item 0 & 0 & 28 & 0 & 0 & 0 & 112 & 80 & Sangat Paham \\
\hline item 11 & 0 & 13 & 15 & 0 & 0 & 97 & 69 & Paham \\
\hline item 12 & 0 & 28 & 0 & 0 & 0 & 112 & 80 & Sangat Paham \\
\hline item 13 & 0 & 28 & 0 & 0 & 0 & 112 & 80 & Sangat Paham \\
\hline item 14 & 0 & 28 & 0 & 0 & 0 & 112 & 80 & Sangat Paham \\
\hline item 15 & 0 & 28 & 0 & 0 & 0 & 112 & 80 & Sangat Paham \\
\hline item 16 & 0 & 28 & 0 & 0 & 0 & 112 & 80 & Sangat Paham \\
\hline
\end{tabular}




\begin{tabular}{|c|c|c|c|c|c|c|c|c|}
\hline \multirow{2}{*}{$\begin{array}{l}\text { item } \\
\text { pernya- } \\
\text { taan }\end{array}$} & $\mathrm{SP}(5)$ & $\mathrm{P}(4)$ & $\mathrm{KP}(3)$ & $\mathrm{TP}(2)$ & STP(1) & \multirow{2}{*}{ Skor } & \multirow{2}{*}{$\begin{array}{c}\text { Persen-tase } \\
\quad(\%)\end{array}$} & \multirow{2}{*}{ Kategori } \\
\hline & $\mathrm{f}$ & $\mathrm{f}$ & $\mathrm{f}$ & $\mathrm{f}$ & $\mathrm{f}$ & & & \\
\hline item 17 & 0 & 25 & 3 & 0 & 0 & 109 & 78 & Sangat Paham \\
\hline item 18 & 0 & 3 & 25 & 0 & 0 & 87 & 62 & Paham \\
\hline item 19 & 0 & 28 & 0 & 0 & 0 & 112 & 80 & Sangat Paham \\
\hline \multirow[t]{2}{*}{ item 20} & 0 & 28 & 0 & 0 & 0 & 112 & 80 & Sangat Paham \\
\hline & \multicolumn{5}{|c|}{ Rata-rata } & 106,3 & 76 & Paham \\
\hline
\end{tabular}

Berdasarkan tabel di atas, terlihat bahwa mayoritas guru sudah sangat paham dalam perencanaan pembelajaran tematik. Sebanyak tujuh (7) item pernyataan dikategorikan paham, indikator tujuh (7) item pernyataan yang dikategorikan paham yaitu indikator penentuan materi pembelajaran, perumusan tujuan, rencana kegiatan, pendekatan saintifik, model pembelajaran, metode pembelajaran dan rancangan penilaian. Sebanyak 13 item pernyataan dikategorikan sangat paham.. Sedangkan item pernyataan yang dikategorikan sangat paham berkenaan dengan indikator STPPA, KIKD, program semester, program mingguan, program harian, langkah pembelajaran, sumber dan media pembelajaran. Sehingga didapat rata-rata pemahaman guru terhadap perencanaan pembelajaran tematik yaitu $76 \%$ dengan kategori paham. Ini artinya bahwa rata-rata pemahaman guru pendidikan anak usia dini terhadap aspek perencanaan pembelajaran tematik sudah paham dengan persentase $76 \%$. Ini artinya bahwa Guru -guru RA SeKecamatan Ajung sudah paham akan perencanaan pembelajaran tematik.

\section{PENUTUP}

\section{Simpulan}

Berdasarkan hasil data dan analisis hasil penelitian yang dilaksanakan di RA SeKecamatan Ajung dan telah diuraikan pada bagian hasil dan pembahasan dapat ditarik kesimpulan bahwa pemahaman guru PAUD terhadap perencanaan pembelajaran tematik dikategorikan sudah paham.

\section{Rekomendasi}

Berdasarkan hasil penelitian, pembahasan dan kesimpulan, maka penelitian ini diharapkan dapat memberikan sumbangsih terhadap peneliti selanjutnya untuk dapat mengembangkan aspek pembelajaran tematik..

\section{DAFTAR PUSTAKA}

Asmawati, Luluk. (2014). Perencanaan Pembelajaran PAUD. Bandung : Rosda

Halimah, Leli. (2016). Pengembangan Kurikulum Pendidikan Anak Usia Dini. Bandung: Refika Aditama

Joni. (2009). Pembelajaran Tematik pada Pendidikan Anak Usia Dini. Jurnal At-Ta'dib. 4(1). 35 - 49.

Majid, Abdul. (2011). Perencanaan Pembelajaran. Bandung : Rosda

Noor, Juliansyah.(2011). Metodologi Penelitian. Jakarta : Prenadamedia

Peraturan Menteri Pendidikan dan Kebudayaan Nomor 146 Tahun 2014 tentang kurikulum 2013 Pendidikan Anak Usia Dini

Peraturan Menteri Pendidikan dan Kebudayaan Nomor 137 Tahun 2014 tentang Standar Nasional Pendidikan Anak Usia Dini

Purwanto, Ngalim.(2012). Prinsip-prinsip dan Teknik Evaluasi Pengajaran. Bandung : Remaja Rosdakarya

Saptiani. (2016). Model Pembelajaran Tematik Anak Usia Dini dalam Kurikulum 2013. JEA.1(1). $14-35$

Sudijono, Anas. (2003). Statistik Pendiidikan. Jakarta : Rajagrafindo Persada

Sugiyono. (2016). Metode Penelitian Kuantitatif, Kualitatif dan $R \& D$. Bandung : Alfabeta

Sujiono, Yuliani Nurani.(2013). Konsep Dasar Pendidikan Anak Usia Dini. Jakarta: Indeks

Undang-Undang Nomor 20 Tahun 2003 tentang Sistem Pendidikan Nasional

Uno. Hamzah B.(2012016). Perencanaan Pembelajaran. Jakarta : Bumi Aksar 